\title{
Clinical Significance of TAP1 and DLL4 Expression in Patients With Locally Advanced Gastric Cancer
}

\author{
KENKI SEGAMI $^{1,2}$, TORU AOYAMA ${ }^{2}$, YUKIHIKO HIROSHIMA ${ }^{3}$, KEISUKE KOMORI $^{1}$, \\ ITARU HASHIMOTO ${ }^{1}$, HAYATO WATANABE ${ }^{1}$, KAZUKI KANO $^{1}$, SHINSUKE NAGASAWA ${ }^{2}$, \\ MASATO NAKAZONO ${ }^{2}$, YUKIO MAEZAWA ${ }^{4}$, HIROHITO FUJIKAWA ${ }^{1}$, MASAKATSU NUMATA ${ }^{2}$, \\ TAKANOBU YAMADA ${ }^{1}$, HIROSHI TAMAGAWA ${ }^{2}$, NAOTO YAMAMOTO ${ }^{2}$, TAKASHI OGATA ${ }^{1}$, \\ MANABU SIOZAWA $^{1}$, NORIO YUKAWA ${ }^{2}$, SOICHIRO MORINAGA ${ }^{1}$, YASUSHI RINO ${ }^{2}$, \\ MUNETAKA MASUDA $^{2}$, YOHEI MIYAGI ${ }^{3}$, HIROSHI SAEKI ${ }^{5}$ and TAKASHI OSHIMA ${ }^{1}$ \\ ${ }^{1}$ Department of Gastrointestinal Surgery, Kanagawa Cancer Center, Yokohama, Japan; \\ ${ }^{2}$ Department of Surgery, Yokohama City University, Yokohama, Japan; \\ ${ }^{3}$ Kanagawa Cancer Center Research Institute, Yokohama, Japan; \\ ${ }^{4}$ Department of Surgery, Tokyo Metropolitan Cancer \\ and Infectious Diseases Center, Komagome Hospital, Tokyo, Japan; \\ ${ }^{5}$ Department of Gastrointestinal Surgery, Gunma University, Gunma, Japan
}

\begin{abstract}
Background/Aim: Cancer stem cells (CSCs) are reported to associated with cancer metastasis, relapse, and chemoresistance. This study examined the clinical significance of the expression of two CSC markers, the transporter associated with antigen processing 1 (TAP1) and the Deltalike 4 (DLL4) protein, in patients with locally advanced GC. Patients and Methods: This study was performed using samples obtained from 413 pathological stage II/III GC patients after curative gastrectomy. We examined TAPI and DLLA expression using immunohistochemical analysis with tissue microarray and examined the association between TAPI or DLL4 expression, clinicopathological factors and survival. Results: High TAP1 expression was associated with better overall survival compared to low TAP1 expression ( $p=0.004$ ). Furthermore, in multivariate analysis, high TAPl expression was defined as a predictive factor for good survival. There was no significant difference between DLL4 expression and clinicopathological features and overall survival. Conclusion: TAP1 expression may be a useful prognostic marker in patients with locally advanced $G C$.
\end{abstract}

This article is freely accessible online.

Correspondence to: Takashi Oshima, Department of Gastrointestinal Surgery, Kanagawa Cancer Center, 2-3-2 Nakao Asahi, Asahi-ku, Yokohama, Kanagawa 241-8515, Japan. Tel: +81 455202222, Fax: +81 455202202, e-mail: oshima@kcch.jp

Key Words: Gastric cancer, cancer stem cell, transporter associated with antigen processing 1, Delta-like 4.
Gastric cancer (GC) has the fifth highest incidence among cancers with $1,089,103$ new cases in 2020, accounting for $5.6 \%$ of all cancers. Importantly, GC is the fourth leading cause of cancer death with 768,793 deaths in 2020, accounting for $7.7 \%$ of all cancer-related deaths (1). The standard treatment for patients with stage II/III GC is curative gastrectomy and postoperative chemotherapy based on the results of three randomised phase III trials, i) ASTSGC, ii) CLASSIC, and iii) JACCRO GC-07 trials (2-6).

Despite the improved outcome of GC patients with these treatments, the five-year overall survival (OS) rate of patients with stage II/III GC remains unsatisfactory $(3,5)$. Therefore, personalised treatment for GC based on biomarkers is considered as one of the strategies to improve the five-year OS rate of patients with stage II/III GC.

In 1997 it was reported that cancer cells originate from a small number of cells, which have self-replication and diversification characteristics of stem cells (7), and these stem cells were named cancer stem cells (CSCs). Subsequently, CSCs have been found in various cancers. CSCs are reported to be resistant to chemotherapy and radiation $(8,9)$. Previous studies have reported that the presence or not of CSCs is associated with the survival of cancer patients $(10,11)$; however, there are insufficient findings regarding the identification of CSC markers that are useful for predicting the prognosis of pathological (p) Stage II/III after curative gastrectomy. Thus, based on the data from the Cancer Genome Atlas, the Human Protein Atlas, and many previous reports on CSC markers $(12,13)$, we focused on two candidate biomarkers for GC: i) the transporter associated with antigen processing 1 (TAP1) and ii) delta-like 4 (DLL4). 


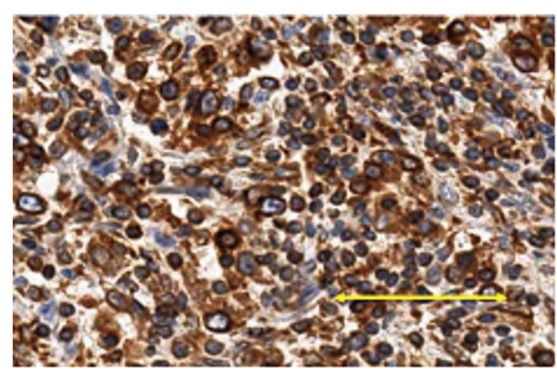

TAP1 3+

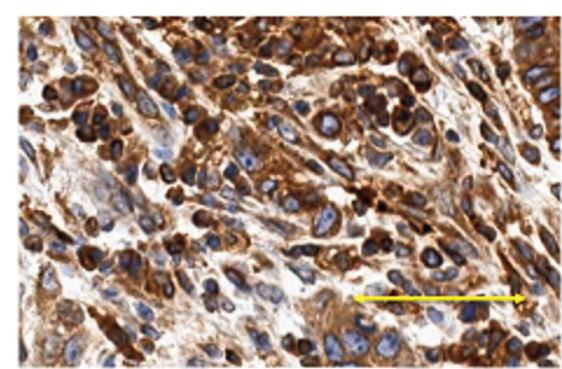

TAP1 2+

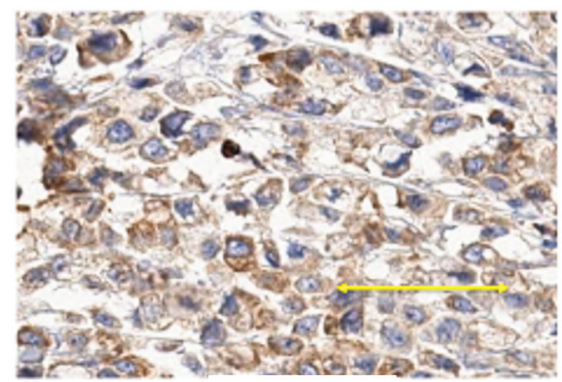

TAP1 1+



TAP1 0

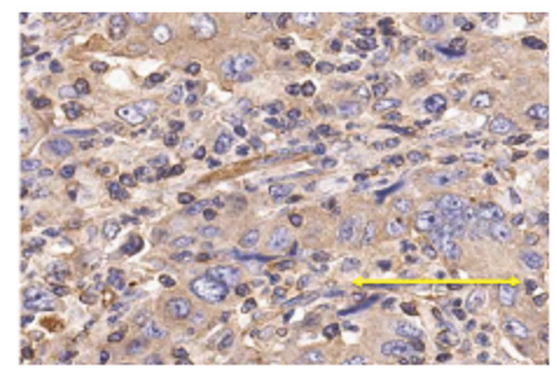

DLL4 3+

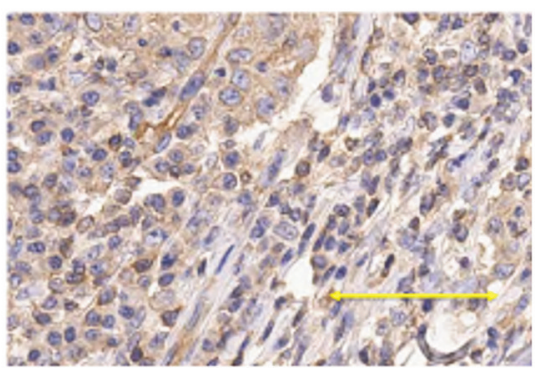

DLL4 2+

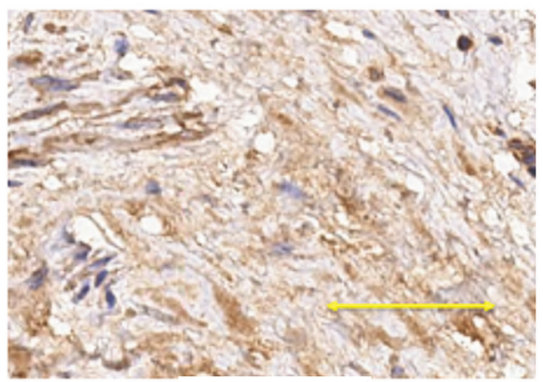

DLL4 1+

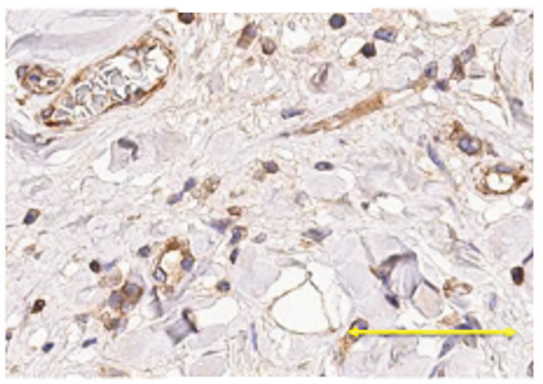

DLL4 0

Figure 1. Representative score of the immunohistochemical staining of transporter associated with antigen processing 1 (TAP1) and Delta-like 4 (DLL4) (brown colour). Expression of TAP1 was observed in the cytoplasm of gastric cancer cells. Expression of DLL4 was observed in the cytoplasm and on cell membrane. Scale bar $=100 \mu \mathrm{m}(400 \times$ magnification).

TAP1 is involved in the transport of antigens from the cytoplasm to the endoplasmic reticulum for association with major histocompatibility complex (MHC) class I molecules. It also acts as a molecular scaffold for the final stage of MHC class I folding, namely peptide binding (14). It has been reported that TAP1 is associated with tumour immune escape, and high expression of TAP1 is a poor prognostic factor for patients with stage I/II colorectal cancer (15). DLL4 is one of five ligands in the Notch signalling pathway (Jagged 1 and 2 and Delta-like ligands 1, 3, and 4) involved in tumorigenesis, tumour progression, tumour angiogenesis, and chemoresistance (16). 
We hypothesised that the expression of these CSC markers might predict the treatment outcomes in patients with pathological (p) Stage II/III GC owing to the characteristics of each protein. This study evaluated the clinical significance of TAP1 and DLL4 expression in cancer tissues of patients with GC who underwent curative gastrectomy.

\section{Patients and Methods}

Patients. The present research was approved by the research ethics committee of the Kanagawa Cancer Centre (No: Epidemiological Study-2019-133). Four hundred and thirteen patients with GC that underwent gastrectomy from August 2002 to August 2012 at the Kanagawa Cancer Centre, Yokohama, Japan, were selected from the clinicopathological database. The inclusion criteria were as follows: i) a pathological diagnosis of gastric adenocarcinoma according to the definitions of the International Union Against Cancer TNM Classification of Malignant Tumours, seventh edition (17), and ii) patients undergoing curative gastrectomy. The exclusion criteria were as follows: i) death before discharge from hospital, ii) receipt of preoperative treatment, and iii) the presence of multiple cancers within five years, and iv) refusal to participate in this study. OS was measured from the day of surgery to death. All patients who participated in this study were briefed on the study and agreed to participate in this study.

Immunohistochemical analysis of TAP1 and DLL4 expression. Paraffin blocks of GC tissues were selected by a pathologist at the Kanagawa Cancer Centre, Yokohama Japan. For tissue microarray, the central and peripheral parts of GC tissues and normal tissue were marked by pathologists. Next, the cylindrical tissue core of the above three marked areas were acquired from each block using a tissue microarray instrument (Beecher Instruments, Sun Prairie, WI, USA). Tissue microarray slides of $5 \mu \mathrm{m}$ thickness were deparaffinized and treated with $10 \mu \mathrm{M}$ sodium citrate buffer for $25 \mathrm{~min}$ for the immunohistochemical analyses. Blocking was carried out with 5\% normal goat serum (Sigma Chemicals, St. Louis, MO, USA) in phosphate-buffered saline with Tween ${ }^{\circledR} 20$ (Takara Bio, Shiga, Japan) and slides were incubated with primary antibodies at $4^{\circ} \mathrm{C}$ for $12 \mathrm{~h}$. Anti-TAP1 antibody (ab137013, Abcam, Cambridge, UK) and anti-DLL4 (ab176876, Abcam) antibodies were both used at a dilution of 1:200. A secondary antibody, the peroxidase-labelled polymer (EnVision ${ }^{\mathrm{TM}}+$ System-HRP, DAKO, Glostrup, Denmark) was used to detect both primary antibodies separately and was terminated before generalized background staining appeared in the negative controls. Sections were then counter stained for 1-2 min with Mayer's haematoxylin.

Immunohistochemical evaluation of TAP1 expression was carried out according to the immunoreactive score (IRS) (18). IRS is a semi-quantitative assessment of expression intensity determined by multiplying the staining intensity in four grades $(0=$ no, $1=$ weak, $2=$ moderate, and $3=$ strong intensity) by the percentage of positive cells in five gradations $(0=$ no, $1 \leq 10 \%, 2=10 \%-50 \%, 3=51 \%-80 \%$, and $4 \geq 80 \%$ ). Based on the resulting IRS score (1-12), patients were divided into the low expression group (IRS $\leq 6)$ and high expression group (IRS $>6$ ).

For the immunohistochemical evaluation of DLL4 expression, staining intensity of DLL4 expression in each tissue was evaluated in four grades $(0=$ no, $1=$ weak, $2=$ moderate, and $3=$ strong intensity $)$ according to the evaluation method by Ishigami et al. (19). DLL4
Table I. Patient characteristics.

\begin{tabular}{lr}
\hline Variables/categories & $\mathrm{n}=413$ \\
\hline Age, median (range) & $65(32-89)$ \\
Gender & \\
$\quad$ Male & $120(29.7 \%)$ \\
Female & $293(70.3 \%)$ \\
Tumour size & \\
$\quad \geq 50$ mm & $187(46.3 \%)$ \\
$\quad<50$ mm & $226(53.7 \%)$ \\
Lauren's classification & \\
Intestinal type & $232(56.3 \%)$ \\
Diffuse type & $181(43.7 \%)$ \\
Tumour depth & \\
T1, T2, T3 & $173(41.9 \%)$ \\
T4 & $240(58.1 \%)$ \\
Lymph-node metastasis & \\
+ + & $348(85.4 \%)$ \\
Pathological stage & $65(14.6 \%)$ \\
II & \\
III & $157(38.0 \%)$ \\
Lymphatic invasion & $256(62.0 \%)$ \\
- & \\
+ & $131(30.6 \%)$ \\
Venous invasion & $282(69.4 \%)$ \\
- & \\
+ & $119(30.6 \%)$ \\
TAP expression & $294(69.4 \%)$ \\
Low & $350(84.7 \%)$ \\
High & $63(15.3 \%)$ \\
DLL4 expression & $306(74.1 \%)$ \\
How & $107(25.9 \%)$ \\
\hline
\end{tabular}

TAP1: Transporter associated with antigen processing 1; DLL4: Deltalike 4.

positivity was defined if tumour cells or stromal cells with a staining intensity of 3 were identified in $>10 \%$ of each tissue. All the arrays were reviewed by two blinded pathologists. Discordant cases were reviewed and discussed until a consensus was reached.

Statistical analyses. The relationship between the expression levels of TAP1 or DLL4 and clinicopathological characteristics were assessed using the Pearson's chi-squared test. OS curves were constructed using the Kaplan-Meier method. The log-rank test was used to test the significance of the OS between the positive and negative expression groups. Univariate and multivariate survival analyses were performed using the Cox proportional hazards regression model. All statistical tests were two-sided, and significance was set at a $p$-Value $<0.05$. The SPSS software package (v11.0 J Win, SPSS, Chicago, IL, USA) was used for all statistical analyses.

\section{Results}

Patients' characteristics. Representative expression levels $(0,1+, 2+, 3+)$ of TAP1 and DELL4 are presented in Figure 1. The clinicopathological characteristics of our patients are 
Table II. Comparison of clinicopathological characteristics between patients with negative and positive TAP1 and DLL4 expression in patients with pStage II/III gastric cancer (GC).

\begin{tabular}{|c|c|c|c|c|c|c|}
\hline & \multicolumn{3}{|c|}{ TAP1 } & \multicolumn{3}{|c|}{ DLL4 } \\
\hline & $\begin{array}{c}\text { Low } \\
(\mathrm{n}=350)\end{array}$ & $\begin{array}{l}\text { High } \\
(\mathrm{n}=63)\end{array}$ & $p$-Value & $\begin{array}{c}\text { Low } \\
(\mathrm{n}=306)\end{array}$ & $\begin{array}{c}\text { High } \\
(\mathrm{n}=107)\end{array}$ & $p$-Value \\
\hline Age, median (range), years & $65(32-89)$ & $67(29-88)$ & 0.253 & $65(35-87)$ & $67(29-89)$ & 0.503 \\
\hline \multicolumn{7}{|l|}{ Gender } \\
\hline Male & $104(29.7 \%)$ & $16(25.4 \%)$ & \multirow[t]{2}{*}{0.549} & $90(29.4 \%)$ & $30(28.0 \%)$ & \multirow[t]{2}{*}{0.902} \\
\hline Female & $246(70.3 \%)$ & $47(74.6 \%)$ & & $216(70.6 \%)$ & $77(72.0 \%)$ & \\
\hline \multicolumn{7}{|l|}{ Tumour size } \\
\hline$\geq 50 \mathrm{~mm}$ & $162(46.3 \%)$ & $25(39.7 \%)$ & \multirow[t]{2}{*}{0.342} & $147(48.0 \%)$ & $40(37.4 \%)$ & \multirow[t]{2}{*}{0.071} \\
\hline$<50 \mathrm{~mm}$ & $188(53.7 \%)$ & $38(60.3 \%)$ & & $159(52.0 \%)$ & $67(62.6 \%)$ & \\
\hline \multicolumn{7}{|l|}{ Lauren's classification } \\
\hline Intestinal type & $197(56.3 \%)$ & $35(55.6 \%)$ & \multirow[t]{2}{*}{0.999} & $135(44.1 \%)$ & $46(43.0 \%)$ & \multirow[t]{2}{*}{0.912} \\
\hline Diffuse type & $153(43.7 \%)$ & $28(44.4 \%)$ & & $171(55.9 \%)$ & $61(57.0 \%)$ & \\
\hline \multicolumn{7}{|l|}{ Tumour depth } \\
\hline $\mathrm{T} 1, \mathrm{~T} 2, \mathrm{~T} 3$ & $142(40.6 \%)$ & $31(49.2 \%)$ & \multirow[t]{2}{*}{0.214} & $131(42.8 \%)$ & $42(39.3 \%)$ & \multirow[t]{2}{*}{0.571} \\
\hline $\mathrm{T} 4$ & $208(59.4 \%)$ & $32(50.8 \%)$ & & $175(57.2 \%)$ & $65(60.7 \%)$ & \\
\hline \multicolumn{7}{|l|}{ Pathological stage } \\
\hline II & $122(34.8 \%)$ & $32(55.6 \%)$ & \multirow[t]{2}{*}{0.007} & $111(36.3 \%)$ & $46(43.0 \%)$ & \multirow[t]{2}{*}{0.184} \\
\hline III & $228(65.2 \%)$ & $28(44.4 \%)$ & & $195(63.7 \%)$ & $61(57.0 \%)$ & \\
\hline \multicolumn{7}{|l|}{ Lymphatic invasion } \\
\hline- & $107(30.6 \%)$ & $24(38.1 \%)$ & \multirow[t]{2}{*}{0.242} & $93(30.4 \%)$ & $39(36.4 \%)$ & \multirow[t]{2}{*}{0.279} \\
\hline+ & $243(69.4 \%)$ & $39(61.9 \%)$ & & $213(69.6 \%)$ & $68(63.6 \%)$ & \\
\hline \multicolumn{7}{|l|}{ Venous invasion } \\
\hline- & $107(30.6 \%)$ & $12(19.0 \%)$ & \multirow[t]{2}{*}{0.070} & $97(31.7 \%)$ & $23(21.5 \%)$ & \multirow[t]{2}{*}{0.040} \\
\hline+ & $243(69.4 \%)$ & $51(81.0 \%)$ & & $209(68.3 \%)$ & $84(78.5 \%)$ & \\
\hline
\end{tabular}

TAP1: Transporter associated with antigen processing 1; DLL4: Delta-like 4. Bold values indicate statistical significance.

A

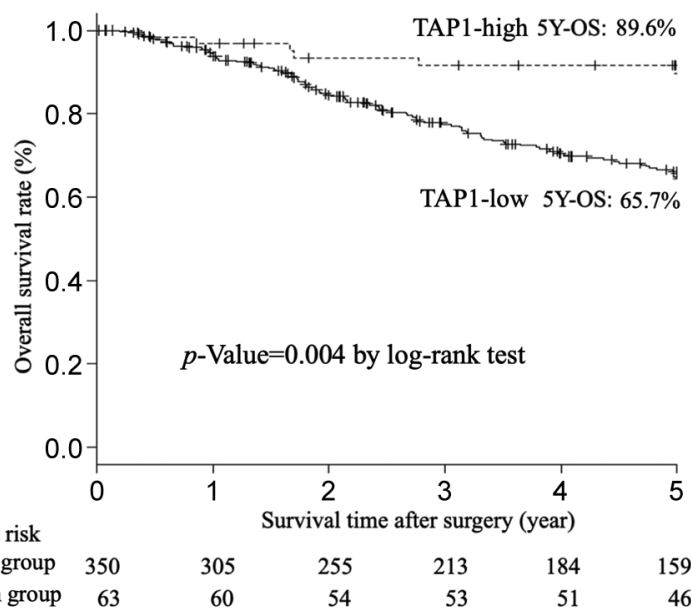

B

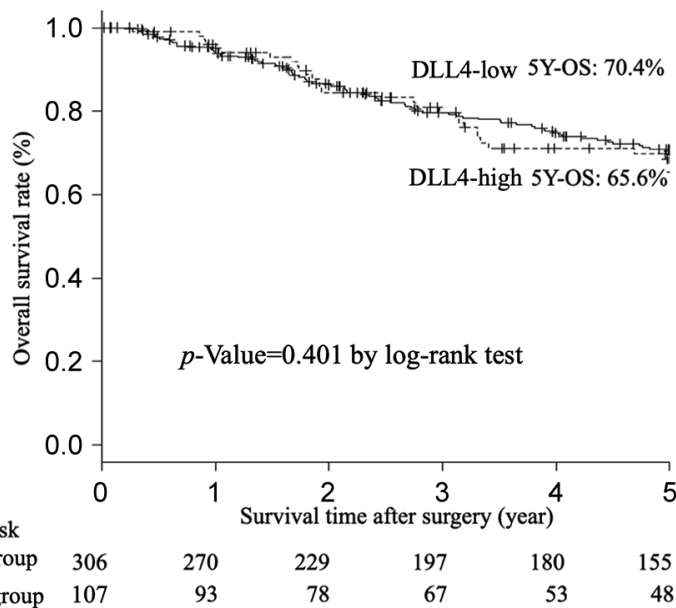

Figure 2. Survival rates. (A) Kaplan-Meier curves and log-rank test for overall survival (OS) rates in TAP1-high and TAP1-low groups. The 5-year OS rate in patients with high and low TAP1 expression were $89.6 \%$ and $65.7 \%$, respectively. High TAP1 expression group had significantly better OS than low TAP1 expression group ( $p=0.004$ by log-rank test). (B) Kaplan-Meier curves and log-rank test for overall survival rates in DLL4-high and DLL4-low groups. The 5-year OS rate in patients with high and low DLL4 expression were $65.5 \%$ and $70.4 \%$, respectively. There was no significant difference between the two groups. 
Table III. Univariate and multivariate analyses of overall survival in patients with gastric cancer ( $n=413)$.

\begin{tabular}{|c|c|c|c|c|c|c|c|}
\hline \multirow[b]{2}{*}{ Variables/categories } & \multirow[b]{2}{*}{$\mathrm{N}$} & \multicolumn{3}{|c|}{ Univariate } & \multicolumn{3}{|c|}{ Multivariate } \\
\hline & & HR & $95 \% \mathrm{CI}$ & $p$-Value & HR & $95 \% \mathrm{CI}$ & $p$-Value \\
\hline Age (years) & & & & 0.012 & & & 0.023 \\
\hline$<70$ & 266 & 1 & & & 1 & & \\
\hline$\geq 70$ & 147 & 1.494 & $1.087-2.053$ & & 1.432 & $1.052-1.948$ & \\
\hline Gender & & & & 0.302 & & & \\
\hline Male & 293 & 1 & & & & & \\
\hline Female & 120 & 0.841 & $0.595-1.192$ & & & & \\
\hline Tumour size & & & & 0.021 & & & 0.012 \\
\hline$<50 \mathrm{~mm}$ & 187 & 1 & & & 1 & & \\
\hline$\geq 50 \mathrm{~mm}$ & 226 & 1.460 & $1.060-2.023$ & & 1.502 & $1.092-2.062$ & \\
\hline Lauren's classification & & & & 0.291 & & & \\
\hline Intestinal type & 181 & 1 & & & & & \\
\hline Diffuse type & 232 & 1.180 & $0.870-1.613$ & & & & \\
\hline Tumour depth & & & & 0.007 & & & 0.004 \\
\hline $\mathrm{T} 1, \mathrm{~T} 2, \mathrm{~T} 3$ & 187 & 1 & & & 1 & & \\
\hline $\mathrm{T} 4$ & 226 & 1.602 & $1.133-2.261$ & & 1.613 & $1.165-2.239$ & \\
\hline Lymph-node metastasis & & & & 0.062 & & & \\
\hline- & 65 & 1 & & & & & \\
\hline+ & 348 & 1.611 & $0.977-2.651$ & & & & \\
\hline Lymphatic invasion & & & & 0.253 & & & \\
\hline - & 131 & 1 & & & & & \\
\hline+ & 282 & 1.234 & $0.551-1.135$ & & & & \\
\hline Venous invasion & & & & 0.201 & & & \\
\hline- & 119 & 1 & & & & & \\
\hline+ & 294 & 1.262 & $0.881-1.816$ & & & & \\
\hline TAP1 expression & & & & $<0.001$ & & & $<0.001$ \\
\hline Low & 350 & 1 & & & 1 & & \\
\hline High & 63 & 0.370 & $0.227-0.618$ & & 0.400 & $0.253-0.662$ & \\
\hline DLL4 expression & & & & 0.172 & & & \\
\hline Low & 306 & 1 & & & & & \\
\hline High & 107 & 1.290 & $0.890-1.891$ & & & & \\
\hline
\end{tabular}

N: Number of patients; HR: hazard ratio; CI: confidence interval; TAP1: transporter associated with antigen processing 1; DLL4: Delta-like 4. Bold values indicate statistical significance.

presented in Table I. Of the 413 patients included in this study, $63(15.2 \%)$ patients had high TAP1 expression, and $107(25.9 \%)$ patients had high DLL4 expression.

Relationship between TAP1 and DLL4 expression and clinicopathological factors. Eight clinicopathological factors were compared separately for high and low expressions of TAP1 and DLL4 (Table II). There were significant differences in the pathological stage of the TAP1 group and in the venous invasion of the DLL4 group.

OS according to the expression level of TAP1 and DLL4. The 5-year OS rate in patients with high and low TAP1 expression was $89.6 \%$ and $65.7 \%$, respectively (Figure 2A). The high TAP1 expression group showed a significantly better OS compared to the low TAP1 expression group ( $p=0.004$ by log-rank test). The 5 -year
OS rate in patients with high and low DLL4 expression was $65.5 \%$ and $70.4 \%$, respectively; however, there was no significant difference between the two groups ( $p=0.401$ by log-rank test) (Figure 2B).

Univariate and multivariate analyses of the relationship between clinicopathological factors. In the univariate and multivariate analyses, we analysed: i) age, ii) sex, iii) tumour size, iv) histogical type (Lauren's classification), v) tumour depth, vi) lymph node metastasis, vii) lymphatic invasion, viii) venous invasion, ix) pathological stage, x) TAP1 expression, and xii) DLL4 expression. In the univariate analyses, age, tumour size, tumour depth, and TAP1 expression were selected as significant factors for OS. In the multivariate analyses, age, tumour size, tumour depth, and TAP1 expression were independent predictive factors of OS after curative gastrectomy in patients with stage II/III GC (Table III). 


\section{Discussion}

In our study, the high expression of TAP1 was significantly associated with better OS. Moreover, TAP1 expression in GC tissues may be a useful prognostic factor in patients with curatively resected GC.

Some studies have reported that the expression of TAP1 in various cancer tissues is associated with the survival of patients or better outcomes, such as in patients with colorectal (15) and breast cancer (20). Other studies have reported no relationship between TAP1 expression and outcomes in patients with ovarian cancer (21) and renal cell carcinoma (22). Finally, according to The Human Protein Atlas data, high TAP1 expression is significantly associated with poor outcomes in patients with lung cancer, renal cell carcinoma, and pancreatic carcinoma (23). Taken together, the relationship between TAP1 expression in cancer tissues and patients' outcomes depends on the type of cancer.

Our study is the first to examine the expression of TAP1 in cancer tissues and outcomes in patients with pStage II/III GC after curative gastrectomy. It has been inferred that the decrease in the expression of human leukocyte antigen class I is induced by low expression level of TAP1, and the increasing proliferative capacity of Ras-transformed human cancer cells is induced by low expression level of TAP1 $(24,25)$. TAP1 expression is involved in antigen presentation by MHC class I and is involved in the transport of antigens from the cytoplasm to the endoplasmic reticulum for their association with $\mathrm{MHC}$ class I molecules. Tumour cells with high TAP1 expression escape CD8(+) cytotoxic $\mathrm{T}$ cell immunity by impairing the MHC class I antigen processing pathway $(15,26,27)$. In addition, low TAP1 expression can elicit tumour immune escape in cancer tissues and give poor outcomes in patients with early-stage breast cancer (20). TAP1 mRNA is expressed in many tissues, and TAP1 protein colocalizes with Ras and Raf at the cell membrane (26). Reducing TAP1 expression by RNA interference can increase Ras/extracellular signalregulated kinase signalling in multiple cell lines derived human carcinoma, such as alveolar adenocarcinoma, cervical carcinoma and breast adenocarcinoma (27). It has also been reported that reducing TAP1 expression increased the proliferative capacity of Ras-transformed human lung, cervical and breast cancer cell lines (27).

For DLL4 expression in gastric cancer, Ishigami et al. (25) have demonstrated that patients with high DLL4 expression have significantly poorer survival compared to those with low DLL4 expression, which is different from our results. Despite this, the same group has reported that DLL4 expression is not an independent prognostic factor in multivariate analysis, similar to our study.

Our study has several limitations. First, although it was conducted using a relatively large number of patients with
GC $(n=413)$, it was a single-centre, retrospective study. To obtain more reliable analysis results regarding the clinical significance of TAP1 in GC, a multicentre study with a larger patient number is necessary. Second, we examined the expression of TAP1 and DLL4 at the central and peripheral parts of each GC tissue using immunostaining; however, considering the heterogeneity, the expression levels of TAP1 and DLL4 at these three parts might not be representative of the whole tumour area.

The mechanisms by which the high TAP1 expression in cancer tissues of patients with GC is significantly associated with better outcomes remain unclear. Our conclusion is that TAP1 expression in GC may be a useful prognostic marker in patients with curatively resected GC.

\section{Conflicts of Interest}

All Authors have no conflicts of interest or financial ties to disclose.

\section{Authors' Contributions}

Concept and study design were conducted by SK, OT, HY, and MY. Data collection and literature search were done by SK and OT. Data analysis and interpretation were done by SK, OT, HY, and MY. Interpretation of data was done by all investigators. The article and figures were drafted by SK and OT. Finally, the article was revised and approved by all investigators. All Authors actively participated in this study.

\section{Acknowledgements}

The Authors would like to thank all the patients, their families, and the site staff for their participation in this study.

\section{References}

1 International Agency for Research on Cancer: Global Cancer observatory. Available at: https:/gco.iarc.fr/today/data/factsheets/ populations/900-world-fact-sheets.pdf [Last accessed on June 19, 2021]

2 Sakuramoto S, Sasako M, Yamaguchi T, Kinoshita T, Fujii M, Nashimoto A, Furukawa H, Nakajima T, Ohashi Y, Imamura H, Higashino M, Yamamura Y, Kurita A, Arai K and ACTS-GC Group: Adjuvant chemotherapy for gastric cancer with S-1, an oral fluoropyrimidine. N Engl J Med 357(18): 1810-1820, 2007. PMID: 17978289. DOI: 10.1056/NEJMoa072252

3 Sasako M, Sakuramoto S, Katai H, Kinoshita T, Furukawa H, Yamaguchi T, Nashimoto A, Fujii M, Nakajima T and Ohashi Y: Five-year outcomes of a randomized phase III trial comparing adjuvant chemotherapy with S-1 versus surgery alone in stage II or III gastric cancer. J Clin Oncol 29(33): 4387-4393, 2011. PMID: 22010012. DOI: 10.1200/JCO.2011.36.5908

4 Bang YJ, Kim YW, Yang HK, Chung HC, Park YK, Lee KH, Lee KW, Kim YH, Noh SI, Cho JY, Mok YJ, Kim YH, Ji J, Yeh TS, Button P, Sirzén F, Noh SH and CLASSIC trial investigators: Adjuvant capecitabine and oxaliplatin for gastric 
cancer after D2 gastrectomy (CLASSIC): a phase 3 open-label, randomised controlled trial. Lancet 379(9813): 315-321, 2012. PMID: 22226517. DOI: 10.1016/S0140-6736(11)61873-4

5 Noh SH, Park SR, Yang HK, Chung HC, Chung IJ, Kim SW, Kim HH, Choi JH, Kim HK, Yu W, Lee JI, Shin DB, Ji J, Chen JS, Lim Y, Ha S, Bang YJ and CLASSIC trial investigators: Adjuvant capecitabine plus oxaliplatin for gastric cancer after D2 gastrectomy (CLASSIC): 5-year follow-up of an open-label, randomised phase 3 trial. Lancet Oncol 15(12): 1389-1396, 2014. PMID: 25439693. DOI: 10.1016/S1470-2045(14)70473-5

6 Yoshida K, Kodera Y, Kochi M, Ichikawa W, Kakeji Y, Sano T, Nagao N, Takahashi M, Takagane A, Watanabe T, Kaji M, Okitsu H, Nomura T, Matsui T, Yoshikawa T, Matsuyama J, Yamada M, Ito S, Takeuchi $M$ and Fujii $M$ : Addition of docetaxel to oral fluoropyrimidine improves efficacy in patients with stage III gastric cancer: Interim analysis of JACCRO GC07, a randomized controlled trial. J Clin Oncol 37(15): 12961304, 2019. PMID: 30925125. DOI: 10.1200/JCO.18.01138

7 Bonnet D and Dick JE: Human acute myeloid leukemia is organized as a hierarchy that originates from a primitive hematopoietic cell. Nat Med 3(7): 730-737, 1997. PMID: 9212098. DOI: 10.1038/nm0797-730

8 Wang JL, Yu JP, Sun ZQ and Sun SP: Radiobiological characteristics of cancer stem cells from esophageal cancer cell lines. World J Gastroenterol 20(48): 18296-18305, 2014. PMID: 25561796. DOI: 10.3748/wjg.v20.i48.18296

9 Go G, Yun CW, Yoon YM, Lim JH, Lee JH and Lee SH: Role of $\mathrm{PrPC}^{\mathrm{C}}$ in cancer stem cell characteristics and drug resistance in colon cancer cells. Anticancer Res 40(10): 5611-5620, 2020. PMID: 32988885. DOI: 10.21873/anticanres.14574

10 Butti R, Gunasekaran VP, Kumar TVS, Banerjee P and Kundu GC: Breast cancer stem cells: Biology and therapeutic implications. Int J Biochem Cell Biol 107: 38-52, 2019. PMID: 30529656. DOI: 10.1016/j.biocel.2018.12.001

11 Stotz M, Herzog SA, Pichler M, Smolle M, Riedl J, Rossmann C, Bezan A, Stöger H, Renner W, Berghold A and Gerger A: Cancer stem cell gene variants in CD44 predict outcome in stage II and stage III colon cancer patients. Anticancer Res 37(4): 2011-2018, 2017. PMID: 28373475. DOI: 10.21873/anticanres. 11545

12 Kim BH, Oh HK, Kim DW, Kang SB, Choi Y and Shin E: Clinical implications of cancer stem cell markers and $\mathrm{ABC}$ transporters as a predictor of prognosis in colorectal cancer patients. Anticancer Res 40(8): 4481-4489, 2020. PMID: 32727778. DOI: 10.21873 /anticanres. 14453

13 Yamashita N, Oyama T, So T, Miyata T, Yoshimatsu T, Nakano R, Matsunaga W and Gotoh A: Association between CD133 expression and prognosis in human lung adenocarcinoma. Anticancer Res 41(2): 905-910, 2021. PMID: 33517296. DOI: 10.21873/anticanres.14843

14 Leone P, Shin EC, Perosa F, Vacca A, Dammacco F and Racanelli V: MHC class I antigen processing and presenting machinery: organization, function, and defects in tumor cells. J Natl Cancer Inst 105(16): 1172-1187, 2013. PMID: 23852952. DOI: $10.1093 /$ jnci/djt184

15 Ling A, Löfgren-Burström A, Larsson P, Li X, Wikberg ML, Öberg Å, Stenling R, Edin S and Palmqvist R: TAP1 downregulation elicits immune escape and poor prognosis in colorectal cancer. Oncoimmunology 6(11): e1356143, 2017. PMID: 29147604. DOI: 10.1080/2162402X.2017.1356143
16 Leslie JD, Ariza-McNaughton L, Bermange AL, McAdow R, Johnson SL and Lewis J: Endothelial signalling by the Notch ligand Delta-like 4 restricts angiogenesis. Development 134(5): 839-844, 2007. PMID: 17251261. DOI: 10.1242/dev.003244

17 Sobin LH, Gospodarowicz MK and Wittekind CH: TNM Classification of Malignant Tumors. $7^{\text {th }}$ edition. John Wiley \& Sons, New York, 2009.

18 Remmele W and Stegner HE: [Recommendation for uniform definition of an immunoreactive score (IRS) for immunohistochemical estrogen receptor detection (ER-ICA) in breast cancer tissue]. Pathologe 8(3): 138-140, 1987. PMID: 3303008.

19 Ishigami S, Arigami T, Uenosono Y, Okumura H, Kurahara H, Uchikado Y, Setoyama T, Kita Y, Kijima Y, Nishizono Y, Nakajo A, Owaki T, Ueno S and Natsugoe S: Clinical implications of DLL4 expression in gastric cancer. J Exp Clin Cancer Res 32: 46, 2013. PMID: 23898884. DOI: 10.1186/1756-9966-32-46

20 Henle AM, Nassar A, Puglisi-Knutson D, Youssef B and Knutson KL: Downregulation of TAP1 and TAP2 in early stage breast cancer. PLoS One 12(11): e0187323, 2017. PMID: 29091951. DOI: 10.1371/journal.pone. 0187323

21 Vitale M, Pelusi G, Taroni B, Gobbi G, Micheloni C, Rezzani R, Donato F, Wang X and Ferrone S: HLA class I antigen downregulation in primary ovary carcinoma lesions: association with disease stage. Clin Cancer Res 11(1): 67-72, 2005. PMID: 15671529.

22 Atkins D, Ferrone S, Schmahl GE, Störkel S and Seliger B: Down-regulation of HLA class I antigen processing molecules: an immune escape mechanism of renal cell carcinoma? J Urol 171(2 Pt 1): 885-889, 2004. PMID: 14713847. DOI: 10.1097/ 01.ju.0000094807.95420.fe

23 The Human Protein Atrlas, TAP1. Available at: https:// www.proteinatlas.org/ENSG00000168394-TAP1/pathology [Last accessed on June 19, 2021]

24 Qin Z, Harders C, Cao X, Huber C, Blankenstein T and Seliger $\mathrm{B}$ : Increased tumorigenicity, but unchanged immunogenicity, of transporter for antigen presentation 1-deficient tumors. Cancer Res 62(10): 2856-2860, 2002. PMID: 12019164.

25 Tanaka K, Tsuchikawa T, Miyamoto M, Maki T, Ichinokawa M, Kubota KC, Shichinohe T, Hirano S, Ferrone S, Dosaka-Akita $\mathrm{H}$, Matsuno $\mathrm{Y}$ and Kondo S: Down-regulation of Human Leukocyte Antigen class I heavy chain in tumors is associated with a poor prognosis in advanced esophageal cancer patients. Int J Oncol 40(4): 965-974, 2012. PMID: 22134332. DOI: 10.3892/ijo.2011.1274

26 Lankat-Buttgereit B and Tampé R: The transporter associated with antigen processing: function and implications in human diseases. Physiol Rev 82(1): 187-204, 2002. PMID: 11773612. DOI: 10.1152 physrev.00025.2001

27 Johnson KG and Kornfeld K: The CRAL/TRIO and GOLD domain protein TAP-1 regulates RAF-1 activation. Dev Biol 341(2): 464-471, 2010. PMID: 20230813. DOI: 10.1016/ j.ydbio.2010.03.003
Received May 1, 2021

Revised June 20, 2021

Accepted July 1, 2021 